\title{
Phenotypic analysis of milk coagulation properties and mineral content of Pinzgauer cattle breed
}

\author{
Carmen L. Manuelian ${ }^{1}$, Mauro Penasa ${ }^{1}$, Giulio Visentin ${ }^{1,2}$, Martino Cassandro ${ }^{1}$, and \\ Massimo De Marchi ${ }^{1}$ \\ ${ }^{1}$ Department of Agronomy, Food, Natural Resources, Animals and Environment, University of Padova, \\ Legnaro (PD), 35020, Italy \\ ${ }^{2}$ Associazione Nazionale Allevatori Frisona Italiana (ANAFI), Cremona, 26100, Italy \\ Correspondence: Carmen L. Manuelian (carmenloreto.manuelianfuste@unipd.it)
}

Received: 5 February 2018 - Revised: 18 May 2018 - Accepted: 30 May 2018 - Published: 13 June 2018

\begin{abstract}
This study aimed to characterize milk coagulation properties (rennet coagulation time, curd-firming time and curd firmness $30 \mathrm{~min}$ after rennet addition to milk) and major mineral contents ( $\mathrm{Ca}, \mathrm{Mg}, \mathrm{P}, \mathrm{K}$ and $\mathrm{Na}$ ) in Pinzgauer dual-purpose cattle breed. The edited dataset consisted of 7763 milk observations from 851 cows reared in 60 herds in the Alpine area of Bolzano province (Italy). Data were analysed through a linear mixed model which included stage of lactation, parity and their interaction as fixed effects, and cow and herd test date as random effects. Rennet coagulation time, curd-firming time and curd firmness 30 min after rennet addition to milk averaged $22.66 \mathrm{~min}, 5.53 \mathrm{~min}$ and $16.79 \mathrm{~mm}$, respectively. The most abundant minerals were $\mathrm{P}$ (1495 mg kg-1$)$ and $\mathrm{Ca}\left(1344 \mathrm{mg} \mathrm{kg}^{-1}\right)$, and the least abundant $\mathrm{Mg}\left(141 \mathrm{mg} \mathrm{kg}^{-1}\right)$. Compared to their older contemporaries, early-lactating younger animals yielded milk that was more favourable for cheese production (i.e. with shorter coagulation time and stronger curd firmness). Mineral contents were lower in milk of primiparous than multiparous cows, except for $\mathrm{Na}$. Moreover, $\mathrm{Ca}, \mathrm{Mg}, \mathrm{P}$ and $\mathrm{Na}$ contents decreased from parturition to peak of lactation and increased thereafter, except for $\mathrm{K}$, which exhibited an opposite trend. Our results showed that Pinzgauer breed produced milk with better coagulation properties and mineral content, from a technological point of view, in first than later parities and in early than late lactation. The characterization of milk coagulation properties and mineral content in autochthonous breeds is important to increase their value and marketability of their products.
\end{abstract}

\section{Introduction}

Autochthonous breeds are important for the conservation of animal genetic resources, the adaptability to their native environment and the ability to exploit natural feeding resources such as grazing (Petrera et al., 2016). Moreover, they play an important role in the preservation of rural landscapes and in creating a link between their products and the area of origin (Sturaro et al., 2010). The dual-purpose (dairy and beef) Pinzgauer (PI) breed is a medium-sized local cattle originating from the native red Bavarian cattle. It includes less than $6 \%$ of Red Holstein genetics as a result of crossbreeding with Red Holstein in the past (Caroli et al., 2010), and is mainly reared in Austria (Salzburg, Tyrol, Carinthia, Styria), Italy (South Tyrol) and Germany (Bavaria). As re- ported by Manuelian et al. (2018), Bolzano province (South Tyrol) accounts for approximately $80 \%$ of the Italian PI population (2104 heads in 2016). Pinzgauer cows are appreciated because of their hardiness, resilience, longevity and adaptability to highland pastures (http://www.pinzgauerrind.at/en/ cattle/pinzgauer-cattle/, 20 January 2018). Milk yield averages $21 \mathrm{~kg} \mathrm{day}^{-1}$ and fat, protein, casein and somatic cell score (SCS) average $4.01 \%, 3.44 \%, 2.72 \%$ and 2.80 , respectively (Manuelian et al., 2018). Full details on PI milk fat composition can be retrieved from Manuelian et al. (2018).

Milk is the main source of $\mathrm{Ca}$ in human diet (Haug et al., 2007; Bonjour et al., 2009; Zamberlin et al., 2012). Also, $\mathrm{Ca}, \mathrm{P}$ and $\mathrm{Mg}$ are partially bonded to the casein micelles (Gaucheron, 2005; Zamberlin et al., 2012), influencing mi- 
celle structure and stability, and thus milk coagulation and curd rheology (Bijl et al., 2013; Malacarne et al., 2014; Petrera et al., 2016; Lucey et al., 2017). Concentrations of Ca, $\mathrm{P}$ and $\mathrm{Mg}$ in milk are negatively correlated with rennet coagulation time (RCT, min) and curd-firming time $\left(k_{20}, \mathrm{~min}\right)$, and positively correlated with curd firmness $30 \mathrm{~min}$ after rennet addition $\left(a_{30}, \mathrm{~mm}\right)$ and titratable acidity (Toffanin et al., 2015; Visentin et al., 2018). Prediction models for major milk minerals have been developed using spectra data recorded through mid-infrared spectroscopy (Soyeurt et al., 2009; Toffanin et al., 2015; Visentin et al., 2016). This has facilitated the phenotypic characterization of cattle breeds (Visentin et al., 2018), otherwise impossible for the limitations of the standard methods (laborious, expensive and timeconsuming). Phenotyping local breeds for particular technological and nutritional properties could help farmers to improve marketability of their products and favour their sustainability and conservation. Therefore, the aim of the present study was to assess the phenotypic variation of predicted milk coagulation properties (MCPs) and major mineral contents of PI local cattle breed.

\section{Material and methods}

\subsection{Origin of the data}

Routine cow milk testing analyses and milk spectra information from PI cattle reared in Bolzano province (northern Italy) spanning a 4-year period (2011 to 2014) were retrieved from the Breeders Association of Bolzano province (Bolzano, Italy) and the South Tyrolean Dairy Association (Bolzano, Italy). Bolzano province is a mountainous area of the Italian Alps, characterized by small farms with traditional feeding (forage or hay and concentrates), and cows are usually moved to highland pastures during the summer season. Immediately after collection, individual milk samples from monthly milk recording procedures were added with Bronysolv preservative (ANA.LI.TIK Austria, Vienna, Austria), and transported to the laboratory of the South Tyrolean Dairy Association for the analysis.

According to International Committee for Animal Recording recommendations, milk fat, protein, casein, and lactose percentages were determined using MilkoScan FT6000 (Foss, Hillerød, Denmark), and somatic cell count (SCC) was assessed by Cell Fossomatic 250 (Foss, Hillerød, Denmark). Moreover, mid-infrared spectra of the analysed samples were stored to allow the a posteriori prediction of MCPs and mineral contents using prediction models developed by Visentin et al. (2016). Briefly, in 2014 a reference dataset containing information on 923 individual cow milk samples from several cattle breeds was collected in Bolzano province. The reference analysis for MCPs (lactodynamography) was performed on all samples and the reference analysis for milk minerals (inductively coupled plasma optical emission spectrometry) was conducted on a repre- sentative subset of 251 cows. Equations to predict MCPs and milk minerals were built using partial least squares regression analysis, after running an uninformative variable elimination procedure as in Gottardo et al. (2015). Coefficients of determination (root mean square errors) in external validation were $0.54(2.90 \mathrm{~min}), 0.56(1.22 \mathrm{~min}), 0.52$ (9.00 mm), $0.67\left(122.00 \mathrm{mg} \mathrm{kg}^{-1}\right), 0.69\left(120.00 \mathrm{mg} \mathrm{kg}^{-1}\right)$, $0.65\left(12.50 \mathrm{mg} \mathrm{kg}^{-1}\right), \quad 0.40 \quad\left(70.00 \mathrm{mg} \mathrm{kg}^{-1}\right)$ and 0.68 $\left(88.12 \mathrm{mg} \mathrm{kg}^{-1}\right.$ ) for RCT, $k_{20}, a_{30}, \mathrm{Ca}, \mathrm{K}, \mathrm{Mg}, \mathrm{Na}$ and $\mathrm{P}$, respectively.

\subsection{Data editing}

The original dataset consisted of 19726 observations from 1558 PI cows. Only records between 6 and 450 days in milk (DIM), and between parity 1 to 9 were retained. Age at calving of each cow was checked to ensure consistency with parity order of the animal, and cows whose age at calving deviated more than 3 standard deviations (SD) from the respective parity mean were discarded from the dataset. Inconsistent information on milk yield, SCC and MCPs was removed from the dataset, as well as milk composition traits and mineral contents that were outside the range mean $\pm 3 \mathrm{SD}$. The SCC was transformed to somatic cell score (SCS) following Eq. (1):

$\mathrm{SCS}=3+\log _{2}(\mathrm{SCC} / 100)$,

where SCC was expressed as cells $\mu \mathrm{L}^{-1}$ (Wiggans and Shook, 1987). Contemporary groups were defined as cows tested in the same herd and date (herd test date, HTD), and HTDs with fewer than three animals were removed from the database, as well as cows with fewer than three observations within lactation. After editing, the final dataset consisted of 7763 observations from 851 cows and 60 herds. Parity averaged $2.75 \pm 1.74$ and average herd size was $14.18 \pm 9.70$ cows, ranging from 3 to 40 .

\subsection{Statistical analysis}

Milk coagulation properties and mineral contents were analysed through a generalized linear model using the MIXED procedure of SAS v9.4 (SAS Institute Inc., Cary, NC). The model was following Eq. (2):

$y_{i j k l m}=$

$\mu+S_{i}+$ Parity $_{j}+\left(S \times\right.$ Parity $_{i j}+\mathrm{HTD}_{k}+$ Cow $_{l}+\epsilon_{i j k l m}$,

where $y_{i j k l m}$ is the dependent variable, $\mu$ is the overall intercept of the model, $S_{i}$ is the fixed effect of the $i$ th class of stage of lactation $(i=1$ to 13 , the first being a class from 6 to 30 DIM, followed by 11 classes of 30 DIM each, and the last being a class from 361 to 450 DIM), Parity $j$ is the fixed effect of the $j$ th class of parity of the cow $(j=1$ to 6 , with the last including parities 6 to 9$),(S \times \text { Parity })_{i j}$ is the fixed interaction effect between stage of lactation and parity, $\mathrm{HTD}_{k}$ 
Table 1. Descriptive statistics of milk yield, somatic cell score (SCS), chemical composition, coagulation properties and mineral contents of Pinzgauer cattle breed $(n=7763)$.

\begin{tabular}{lrrrr}
\hline Trait & Mean & $\mathrm{CV}^{2} \%$ & Minimum & Maximum \\
\hline Milk yield & 21.51 & 31.58 & 3.30 & 42.10 \\
kg day $^{-1}$ ) & & & & \\
SCS & 2.53 & 66.33 & -2.06 & 9.43 \\
\hline Milk composition (\%) & & & \\
\hline Fat & 3.97 & 15.88 & 2.05 & 5.93 \\
Protein & 3.41 & 10.88 & 2.41 & 4.59 \\
Casein & 2.70 & 10.30 & 1.93 & 3.59 \\
Lactose & 4.86 & 3.37 & 4.25 & 5.36 \\
\hline Milk coagulation properties & & & \\
\hline RCT (min) & 22.66 & 15.01 & 8.44 & 29.99 \\
$k_{20}($ min $)$ & 5.53 & 18.29 & 0.90 & 8.90 \\
$a_{30}(m m)$ & 16.79 & 50.33 & 0.18 & 49.09 \\
\hline Mineral contents (mg kg & & & & \\
\hline Calcium & 1346.96 & 10.66 & 896.93 & 1885.71 \\
Magnesium & 141.41 & 17.59 & 63.35 & 193.81 \\
Potassium & 1495.04 & 8.61 & 1089.39 & 1893.12 \\
Phosphorus & 948.49 & 11.59 & 617.00 & 1291.37 \\
Sodium & 398.03 & 13.01 & 248.18 & 568.74 \\
\hline
\end{tabular}

${ }^{1}$ RCT: rennet coagulation time. $k_{20}$ : curd-firming time. $a_{30}$ : curd firmness $30 \mathrm{~min}$ after rennet addition to milk. ${ }^{2}$ Coefficient of variation.

is the random effect of the $k$ th $\operatorname{HTD}(k=1$ to 1206$) \sim N(0$, $\left.\sigma_{\mathrm{HTD}}^{2}\right), \mathrm{Cow}_{l}$ is the random effect of the $l$ th cow $(l=1$ to $851) \sim N\left(0, \sigma_{\mathrm{COW}}^{2}\right)$, and $\varepsilon_{i j k l m}$ is the random residual $\sim N$ $\left(0, \sigma_{\mathrm{e}}^{2}\right)$. Multiple comparisons of least squares means were performed for the fixed effects using Bonferroni's test. Pearson correlations between traits were assessed using PROC CORR of SAS. Significance was established at $p<0.05$, unless otherwise indicated.

\section{Results and discussion}

\subsection{Descriptive statistics and correlations}

The greatest coefficient of variation (CV) was observed for SCS $(66.33 \%)$ and the lowest for lactose content $(3.37 \%$; Table 1). Among MCPs, $a_{30}$ was the trait with the greatest CV, in agreement with results from other authors (Toffanin et al., 2015; Varotto et al., 2015; Niero et al., 2016). As expected, milk was richer in $\mathrm{K}$ and $\mathrm{Ca}$, and poorer in Mg (Gaucheron, 2005; Soyeurt et al., 2009; Niero et al., 2016; Visentin et al., 2016, 2018). However, among minerals, $\mathrm{K}$ concentration showed the lowest CV (8.61\%) and $\mathrm{Mg}$ the greatest one (17.59\%; Table 1). Considering several breeds reared in Bolzano province, Visentin et al. (2018) reported the greatest variation for $\mathrm{Mg}$ and the lowest for P. On the other hand, in Burlina cattle, another local breed reared in mountain areas, the greatest variability in the milk mineral fraction was observed for $\mathrm{Na}$ (Niero et al., 2016). Compared to the study of Visentin et al. (2018), Pinzgauer milk showed $\mathrm{Ca}$ and $\mathrm{Mg}$ contents that were similar to Brown Swiss milk, $\mathrm{Na}$ and $\mathrm{K}$ contents that were lower than all the breeds included in their study, and $\mathrm{P}$ content that was similar to Holstein-Friesian milk.

Phenotypic correlations between the studied traits are reported in Table 2. We observed moderate to low significant correlations between MCPs and almost all minerals in milk which agreed with Visentin et al. (2018). Toffanin et al. (2015) have reported significant correlations of $a_{30}$ with $\mathrm{Ca}$ and $\mathrm{P}$, but not between RCT and $\mathrm{Ca}$ and P. Among MCPs, strong and negative correlation was obtained between RCT and $a_{30}$, which was consistent with results of Toffanin et al. (2015) and Visentin et al. (2018), and moderate negative correlation between $a_{30}$ and $k_{20}$, as reported by Visentin et al. (2018). Among minerals, Ca was moderately positively correlated with $\mathrm{Mg}$ and $\mathrm{P}$, which agreed with Petrera et al. (2016). Phosphorus was moderately positively correlated with $\mathrm{K}$ and moderately negatively correlated with $\mathrm{Na}$ (Table 2). Casein showed the strongest correlation with $k_{20}$ and $\mathrm{P}$, the former being negative and the latter positive. Moreover, $\mathrm{Ca}$ and $\mathrm{Mg}$ were positively correlated with casein content. These results were consistent with Petrera et al. (2016) and Visentin et al. (2018). The correlations between casein and $\mathrm{Ca}, \mathrm{Mg}$ and $\mathrm{P}$ were expected because these minerals are partially bonded to the casein micelles (Gaucheron, 2005; Zamberlin et al., 2012). Negative moderate correlations were detected between $k_{20}$ and $\mathrm{Ca}, \mathrm{Mg}$ and $\mathrm{P}$, and positive correlations between these minerals and $a_{30}$ (Table 2), which agreed with Toffanin et al. (2015) and Visentin et al. (2018).

\subsection{Parity and stage of lactation}

All fixed effects included in the model were significant in explaining the variation of MCPs and milk mineral contents (Table 3). The random factors showed that MCPs, Ca, P and $\mathrm{Na}$ were more affected by the animal, whereas rearing conditions affected more $\mathrm{Mg}$ and $\mathrm{K}$; in particular, HTD effect explained $85 \%$ of total variance of $\mathrm{Mg}$ (Table 3). Although Zamberlin et al. (2012) and Visentin et al. (2018) have reported a greater dietary effect on $\mathrm{K}$ content than on other minerals, they indicated that $\mathrm{Mg}$ was not affected by the diet, which disagrees with our results.

No relevant differences were detected for RCT across parities, whereas milk from primiparous cows showed the lowest $k_{20}$ and the greatest $a_{30}$ (Table 4). Curd-firming time increased with parity, while $a_{30}$ differed only between first and later parity cows. These results partially agreed with Penasa et al. (2014) and Varotto et al. (2015), who observed shorter RCT and firmer curd in milk of primiparous than multiparous cows. However, Ikonen et al. (2004) reported no effect of parity on MCPs. The greatest $\mathrm{Ca}, \mathrm{Mg}$ and $\mathrm{P}$, and the lowest $\mathrm{Na}$ contents were observed in milk from primiparous cows. Con- 
Table 2. Pearson correlations between milk yield, somatic cell score (SCS), chemical composition, coagulation properties and mineral contents of Pinzgauer cattle breed.

\begin{tabular}{lrrrrrrrrrrrr}
\hline Trait $^{1}$ & Milk yield & SCS & Fat & Casein & Lactose & RCT & $k_{20}$ & $a_{30}$ & Ca & Mg & K & P \\
\hline SCS & -0.21 & & & & & & & & & & & \\
Fat & -0.27 & 0.16 & & & & & & & & & & \\
Casein & -0.46 & 0.16 & 0.56 & & & & & & & & & \\
Lactose & 0.22 & -0.37 & -0.16 & -0.13 & & & & & & & & \\
RCT & -0.07 & 0.14 & $-0.02^{2}$ & 0.14 & -0.18 & & & & & & & \\
$k_{20}$ & 0.32 & -0.04 & -0.51 & -0.69 & 0.02 & 0.24 & & & & & & \\
$a_{30}$ & -0.06 & -0.15 & 0.18 & 0.15 & 0.14 & -0.84 & -0.58 & & & & & \\
Ca & -0.28 & 0.18 & 0.36 & 0.37 & -0.03 & -0.30 & -0.45 & 0.36 & & & & \\
Mg & -0.17 & 0.10 & 0.20 & 0.27 & -0.19 & -0.20 & -0.30 & 0.14 & 0.52 & & & \\
K & -0.03 & 0.03 & -0.29 & -0.26 & -0.11 & -0.10 & 0.07 & $0.02^{2}$ & 0.17 & 0.14 & & \\
P & -0.17 & 0.01 & 0.22 & 0.44 & 0.15 & -0.12 & -0.33 & 0.24 & 0.39 & 0.10 & 0.31 & \\
Na & -0.25 & 0.35 & -0.19 & 0.03 & -0.80 & 0.25 & 0.09 & -0.21 & 0.04 & 0.13 & 0.20 & -0.36 \\
\hline
\end{tabular}

${ }^{1}$ RCT: rennet coagulation time. $k_{20}$ : curd-firming time. $a_{30}$ : curd firmness $30 \mathrm{~min}$ after rennet addition to milk. Ca: calcium. Mg: magnesium. K: potassium. P: phosphorus. Na: sodium. ${ }^{2}$ Correlations not different from zero $(p>0.05)$.

Table 3. $F$ values and significance of fixed effects and proportion of phenotypic variance explained by random effects for milk coagulation properties and mineral contents of Pinzgauer cattle breed.

\begin{tabular}{|c|c|c|c|c|c|c|}
\hline \multirow[t]{2}{*}{ Trait $^{1}$} & \multicolumn{3}{|c|}{ Fixed effects } & \multicolumn{3}{|c|}{$\begin{array}{c}\text { Random effects } \\
\text { (\% of total variance) }\end{array}$} \\
\hline & $\begin{array}{l}\text { Stage of } \\
\text { lactation }\end{array}$ & Parity & $\begin{array}{r}\text { Stage of } \\
\text { lactation } \times \\
\text { Parity }\end{array}$ & $\mathrm{HTD}^{2}$ & Animal & Residual \\
\hline \multicolumn{7}{|c|}{ Milk coagulation properties } \\
\hline $\mathrm{RCT}(\min )$ & $64.57^{* * *}$ & $3.14^{* *}$ & $2.06^{* * *}$ & 24.72 & 43.21 & 32.07 \\
\hline$k_{20}(\min )$ & $205.82^{* * *}$ & $48.13^{* * *}$ & $1.73^{* * *}$ & 18.08 & 46.49 & 35.43 \\
\hline$a_{30}(\mathrm{~mm})$ & $27.97^{* * *}$ & $6.07^{* * *}$ & $2.13^{* * *}$ & 22.96 & 41.87 & 35.17 \\
\hline \multicolumn{7}{|c|}{ Mineral contents $\left(\mathrm{mg} \mathrm{kg}^{-1}\right)$} \\
\hline Calcium & $149.35^{* * *}$ & $16.49^{* * *}$ & $2.02^{* * *}$ & 24.80 & 42.93 & 32.27 \\
\hline Magnesium & $219.12^{* * *}$ & $13.28^{* * *}$ & $1.82^{* * *}$ & 85.25 & 8.89 & 5.86 \\
\hline Potassium & $32.09^{* * *}$ & $31.22^{* * *}$ & $1.48^{* * *}$ & 47.36 & 30.72 & 21.92 \\
\hline Phosphorus & $67.39^{* * *}$ & $67.82^{* * *}$ & $1.32^{*}$ & 22.85 & 52.67 & 24.48 \\
\hline Sodium & $206.95^{* * *}$ & $120.45^{* * *}$ & $4.07^{* * *}$ & 14.18 & 49.65 & 36.17 \\
\hline
\end{tabular}

tent of $\mathrm{Ca}$ and $\mathrm{Mg}$ decreased with parity, while $\mathrm{Na}$ content increased. The decrease of mineral content while increasing parity could be due to a dilution effect of these minerals as a consequence of increasing milk production. Moreover, the decrease of $\mathrm{P}$ and $\mathrm{K}$ and the increase of Na could reflect an increment of the capillary permeability in the mammary gland related to an increase of SCS in multiparous cows (Summer et al., 2009). In addition, the decrease of Ca could be because multiparous cows are less capable of mobilizing $\mathrm{Ca}$ from bone and express fewer intestinal and bone vitamin D receptors (Horst et al., 1994; Moore et al., 2000; Taylor et al., 2008).
Rennet coagulation time increased until 4 months after calving and reached a plateau in the remaining part of lactation. The $k_{20}$ decreased until 9 months from parturition and remained stable thereafter. The greatest $a_{30}$ was observed at the onset of the lactation, it reached the lowest values between 1 and 7 months after calving, and increased thereafter. The better MCPs in early lactation agreed with the trend described by several authors (Ikonen et al., 2004; De Marchi et al., 2007; Penasa et al., 2014; Varotto et al., 2015; Visentin et al., 2015). Concentration of $\mathrm{Ca}$ and $\mathrm{Mg}$ decreased and then increased until 10 months from calving, while $\mathrm{Na}$ increased during lactation until 9 months from calving. For K, 
Table 4. Least squares means of milk coagulation properties and mineral contents in different parities and stages of lactation of Pinzgauer cattle breed.

\begin{tabular}{|c|c|c|c|c|c|c|c|c|}
\hline \multirow[b]{2}{*}{ Effect } & \multicolumn{3}{|c|}{ Milk coagulation properties ${ }^{1}$} & \multicolumn{5}{|c|}{ Mineral contents $\left(\mathrm{mg} \mathrm{kg}^{-1}\right)$} \\
\hline & $\mathrm{RCT}$ (min) & $k_{20}(\min )$ & $a_{30}(\mathrm{~mm})$ & Calcium & Magnesium & Potassium & Phosphorus & Sodium \\
\hline \multicolumn{9}{|l|}{ Parity } \\
\hline First & $22.83^{b}$ & $5.08^{\mathrm{e}}$ & $17.77^{\mathrm{a}}$ & $1392.85^{\mathrm{a}}$ & $146.53^{\mathrm{a}}$ & $1514.49^{\mathrm{a}}$ & $995.30^{\mathrm{a}}$ & $379.53^{d}$ \\
\hline Second & $23.15^{\mathrm{a}}$ & $5.28^{\mathrm{d}}$ & $16.66^{\mathrm{b}}$ & $1369.15^{\mathrm{b}}$ & $144.45^{\mathrm{b}}$ & $1484.23^{\mathrm{b}, \mathrm{c}, \mathrm{d}}$ & $951.94^{\mathrm{b}}$ & $406.67^{\mathrm{c}}$ \\
\hline Third & $22.91^{\mathrm{a}, \mathrm{b}}$ & $5.43^{\mathrm{c}}$ & $16.81^{b}$ & $1357.33^{\mathrm{b}, \mathrm{c}}$ & $144.12^{\mathrm{b}, \mathrm{c}}$ & $1477.56^{\mathrm{c}, \mathrm{d}}$ & $940.27^{\mathrm{c}}$ & $413.75^{b}$ \\
\hline Fourth & $22.83^{\mathrm{a}, \mathrm{b}}$ & $5.59^{\mathrm{b}}$ & $16.38^{b}$ & $1361.34^{b}$ & $142.75^{\mathrm{d}}$ & $1471.72^{\mathrm{d}}$ & $934.15^{\mathrm{c}}$ & $418.17^{\mathrm{a}, \mathrm{b}}$ \\
\hline Fifth & $22.94^{\mathrm{a}, \mathrm{b}}$ & $5.81^{\mathrm{a}}$ & $15.72^{b}$ & $1343.08^{\mathrm{c}, \mathrm{d}}$ & $142.59^{\mathrm{d}, \mathrm{c}}$ & $1494.93^{\mathrm{b}}$ & $937.99^{b, c}$ & $423.07^{\mathrm{a}}$ \\
\hline Six and later & $22.97^{\mathrm{a}, \mathrm{b}}$ & $5.94^{\mathrm{a}}$ & $15.45^{\mathrm{b}}$ & $1327.58^{d}$ & $140.99^{d}$ & $1496.41^{\mathrm{a}, \mathrm{b}, \mathrm{c}}$ & $934.11^{\mathrm{b}, \mathrm{c}}$ & $424.86^{\mathrm{a}}$ \\
\hline \multicolumn{9}{|c|}{ Lactation stage (day) } \\
\hline $6-30$ & $20.51^{\mathrm{e}}$ & $5.63^{\mathrm{c}}$ & $19.82^{\mathrm{a}}$ & $1313.09^{\mathrm{e}, \mathrm{f}}$ & $139.12^{\mathrm{g}}$ & $1524.99^{\mathrm{a}}$ & $969.71^{\mathrm{b}, \mathrm{c}}$ & $365.44^{\mathrm{i}}$ \\
\hline $31-60$ & $21.85^{\mathrm{d}}$ & $6.34^{\mathrm{a}}$ & $15.81^{\mathrm{b}, \mathrm{e}, \mathrm{f}}$ & $1295.33^{\mathrm{f}, \mathrm{g}}$ & $134.25^{\mathrm{i}}$ & $1525.70^{\mathrm{a}}$ & $915.91^{\mathrm{g}}$ & $375.99^{h}$ \\
\hline 61-90 & $22.49^{\mathrm{c}}$ & $6.22^{\mathrm{a}}$ & $15.15^{\mathrm{e}, \mathrm{f}}$ & $1298.01^{\mathrm{f}, \mathrm{g}}$ & $135.46^{\mathrm{i}}$ & $1511.64^{b}$ & $916.01^{\mathrm{g}}$ & $386.40^{\mathrm{g}}$ \\
\hline $91-120$ & $23.01^{b}$ & $6.01^{\mathrm{d}}$ & $14.87^{\mathrm{f}}$ & $1293.88^{\mathrm{g}}$ & $137.02^{\mathrm{h}}$ & $1501.22^{\mathrm{b}, \mathrm{c}}$ & $920.90^{f, g}$ & $395.82^{f}$ \\
\hline $121-150$ & $23.23^{\mathrm{a}, \mathrm{b}}$ & $5.87^{\mathrm{e}}$ & $14.84^{\mathrm{f}}$ & $1298.74^{f, g}$ & $138.69^{\mathrm{g}}$ & $1493.44^{\mathrm{c}, \mathrm{d}}$ & $921.91^{\mathrm{f}, \mathrm{g}}$ & $402.89^{\mathrm{e}}$ \\
\hline $151-180$ & $23.35^{\mathrm{a}, \mathrm{b}}$ & $5.78^{\mathrm{e}}$ & $15.12^{\mathrm{e}, \mathrm{f}}$ & $1304.78^{\mathrm{e}, \mathrm{g}}$ & $140.90^{f}$ & $1492.47^{\mathrm{c}, \mathrm{d}}$ & $928.47^{\mathrm{e}, \mathrm{f}}$ & $412.59^{d}$ \\
\hline $181-210$ & $23.34^{\mathrm{a}, \mathrm{b}}$ & $5.61^{\mathrm{c}}$ & $15.51^{\mathrm{d}, \mathrm{e}, \mathrm{f}}$ & $1320.05^{\mathrm{e}}$ & $143.13^{\mathrm{e}}$ & $1485.69^{\mathrm{d}, \mathrm{e}}$ & $934.68^{\mathrm{d}, \mathrm{e}}$ & $416.40^{\mathrm{d}}$ \\
\hline $211-240$ & $23.40^{\mathrm{a}, \mathrm{b}}$ & $5.41^{\mathrm{f}}$ & $16.14^{\mathrm{b}, \mathrm{d}, \mathrm{e}}$ & $1351.57^{d}$ & $145.65^{d}$ & $1481.34^{\mathrm{d}, \mathrm{e}}$ & $943.16^{\mathrm{d}}$ & $423.24^{\mathrm{c}}$ \\
\hline $241-270$ & $23.36^{\mathrm{a}, \mathrm{b}}$ & $5.10^{\mathrm{g}}$ & $17.17^{\mathrm{b}, \mathrm{c}}$ & $1395.96^{\mathrm{c}}$ & $147.64^{\mathrm{c}}$ & $1470.60^{f}$ & $960.92^{c}$ & $425.64^{b, c}$ \\
\hline $271-300$ & $23.37^{\mathrm{a}, \mathrm{b}}$ & $5.02^{\mathrm{g}, \mathrm{h}}$ & $17.30^{\mathrm{b}, \mathrm{c}}$ & $1422.70^{b}$ & $149.23^{\mathrm{b}, \mathrm{c}}$ & $1462.84^{\mathrm{f}}$ & $965.92^{c}$ & $432.46^{\mathrm{a}}$ \\
\hline $301-330$ & $23.63^{\mathrm{a}}$ & $4.91^{\mathrm{h}}$ & $16.99^{\mathrm{b}, \mathrm{c}, \mathrm{d}}$ & $1444.12^{\mathrm{a}, \mathrm{b}}$ & $151.68^{\mathrm{a}}$ & $1474.17^{\mathrm{e}, \mathrm{f}}$ & $972.38^{\mathrm{b}, \mathrm{c}}$ & $438.91^{\mathrm{a}, \mathrm{b}}$ \\
\hline $331-360$ & $23.31^{\mathrm{a}, \mathrm{b}}$ & $4.96^{\mathrm{g}, \mathrm{h}}$ & $17.54^{\mathrm{b}, \mathrm{c}}$ & $1450.62^{\mathrm{a}, \mathrm{b}}$ & $151.03^{\mathrm{a}, \mathrm{b}}$ & $1472.09^{\mathrm{d}, \mathrm{f}}$ & $987.99^{\mathrm{a}, \mathrm{b}}$ & $435.09^{\mathrm{a}, \mathrm{b}}$ \\
\hline $361-450$ & $23.37^{\mathrm{a}, \mathrm{b}}$ & $4.90^{\mathrm{g}, \mathrm{h}}$ & $17.75^{\mathrm{b}, \mathrm{c}}$ & $1472.39^{\mathrm{a}}$ & $152.60^{\mathrm{a}}$ & $1472.38^{\mathrm{d}, \mathrm{f}}$ & $998.50^{\mathrm{a}}$ & $432.22^{\mathrm{a}, \mathrm{b}, \mathrm{c}}$ \\
\hline
\end{tabular}

Least squares means with different superscript letters within trait and effect are significantly different $(p<0.05) .{ }^{1}$ RCT: rennet coagulation time. $k_{20}$ : curd-firming time. $a_{30}$ : curd firmness $30 \mathrm{~min}$ after rennet addition to milk.

the greatest values were observed at the beginning of the lactation, whereas $\mathrm{P}$ showed the lowest values between 1 and 4 months of lactation, which agreed with Gaucheron (2005) and Visentin et al. (2018), who also reported greater values for $\mathrm{K}$ and $\mathrm{P}$ in early and mid-lactation. The lactation curve could explain differences in milk mineral content across DIM because the lowest mineral content (greatest for K) was observed at the peak of lactation, and the greatest mineral content (lowest for $\mathrm{K}$ ) at the end of the lactation. Sodium is the major extracellular cation and $\mathrm{K}$ is the major intracellular cation; thus, the opposite pattern observed between $\mathrm{Na}$ and $\mathrm{K}$ across lactation is due to the sodium-potassium pump that regulates osmotic pressure between the cytoplasm of blood cells and milk (Zamberlin et al., 2012). The lower level for $\mathrm{Ca}$ in early lactation could be related to the negative $\mathrm{Ca}$ balance during the first weeks after calving because during this period intestine $\mathrm{Ca}$ absorption, bone $\mathrm{Ca}$ mobilization and feed intake are not at their full potential (Horst et al., 1994).

\section{Conclusions}

Our results showed that parity and stage of lactation significantly affected coagulation properties and mineral contents of milk from PI cattle breed. In particular, PI cows produced milk with more favourable coagulation properties and mineral content, from a technological point of view, in first than later parities and in early than late lactation. Milk coagulation traits were moderately correlated with $\mathrm{Ca}, \mathrm{Mg}$ and $\mathrm{P}$ content, probably because those minerals are included in the casein micelles. The characterization of MCPs and mineral contents, which are relevant economic traits for the dairy sector, is important to increase the value and marketability of local breeds and their products.

Data availability. The data of the paper are available upon request from the corresponding author.

Author contributions. CLM performed part of the statistical analyses and drafted the manuscript. MP was involved in drafting the paper and in statistical analyses. GV contributed to statistical analyses. MDM and MC designed the research. All authors contributed to the discussion of the results and approved the final draft of the manuscript. 
Competing interests. The authors declare that they have no conflict of interest.

Acknowledgements. The authors gratefully acknowledge the milk laboratory of the South Tyrolean Dairy Association (Bolzano, Italy) and the Breeders Association of Bolzano province (Bolzano, Italy) for providing data used in this study. This research did not receive any specific grant from funding agencies in the public, commercial or not-for-profit sectors.

Edited by: Nina Melzer

Reviewed by: Janak Vidanarachi and Gustav Chladek

\section{References}

Bijl, E., van Valenberg, H. J. F., Huppertz, T., and van Hooijdonk, A. C. M.: Protein, casein, and micellar salts in milk: Current content and historical perspectives, J. Dairy Sci., 96, 5455-5464, 2013.

Bonjour, J.-P., Guéguen, L., Palacios, C., Shearer, M. J., and Weaver, C. M.: Minerals and vitamins in bone health: the potential value of dietary enhancement, Br. J. Nutr., 101, 1581-1596, 2009.

Caroli, A., Rizzi, R., Lühken, G., and Erhardt, G.: Short communication: Milk protein genetic variation and casein haplotype structure in the Original Pinzgauer cattle, J. Dairy Sci., 93, 1260$1265,2010$.

De Marchi, M., Dal Zotto, R., Cassandro, M., and Bittante, G.: Milk coagulation ability of five dairy cattle breeds, J. Dairy Sci. 90, 3986-3992, 2007.

Gaucheron, F.: The minerals of milk, Reprod. Nutr. Dev., 45, 473483, 2005.

Gottardo, P., De Marchi, M., Cassandro, M., and Penasa, M.: Technical note: Improving the accuracy of mid-infrared prediction models by selecting the most informative wavelengths, J. Dairy Sci., 98, 4168-4173, 2015.

Haug, A., Høstmark, A. T., and Harstad, O. M.: Bovine milk in human nutrition - a review, Lipids Health Dis., 6, 1-16, https://doi.org/10.1186/1476-511X-6-25, 2007.

Horst, R. L., Goff, J. P., and Reinhardt, T. A.: Calcium and vitamin D metabolism in the dairy cow, J. Dairy Sci., 77, 1936-1951, 1994.

Ikonen, T., Morri, S., Tyrisevä, A. M., Ruottinen, O., and Ojala, M.: Genetic and phenotypic correlations between milk coagulation properties, milk production traits, somatic cell count, casein content, and pH of milk, J. Dairy Sci., 87, 458-467, 2004.

Lucey, J. A., Otter, D., and Horne, D. S.: A 100-Year Review: Progress on the chemistry of milk and its components, J. Dairy Sci., 100, 9916-9932, 2017.

Malacarne, M., Franceschi, P., Formaggioni, P., Sandri, S., Mariani, P., and Summer, A.: Influence of micellar calcium and phosphorus on rennet coagulation properties of cows milk, J. Dairy Res., 81, 129-136, 2014.

Manuelian, C. L., Visentin, G., Penasa, M., Cassandro, M., and De Marchi, M.: Phenotypic variation of milk fatty acid composition of Pinzgauer cattle breed, Ital. J. Anim. Sci., 17, 574-577, 2018.

Moore, S. J., VandeHaar, M. J., Sharma, B. K., Pilbeam, T. E., Beede, D. K., Bucholtz, H. F., Liesman, J. S., Horst, R. L., and
Goff, J. P.: Effects of altering dietary cation-anion difference on calcium and energy metabolism in peripartum cows, J. Dairy Sci., 83, 2095-2104, 2000.

Niero, G., Visentin, G., Ton, S., De Marchi, M., Penasa, M., and Cassandro, M.: Phenotypic characterisation of milk technological traits, protein fractions, and major mineral and fatty acid composition of Burlina cattle breed, Ital. J. Anim. Sci., 15, 576-583, 2016.

Penasa, M., Tiezzi, F., Sturaro, A., Cassandro, M., and De Marchi, M.: A comparison of the predicted coagulation characteristics and composition of milk from multi-breed herds of HolsteinFriesian, Brown Swiss and Simmental cows, Int. Dairy J., 35, 6-10, 2014.

Petrera, F., Catillo, G., Napolitano, F., Malacarne, M., Franceschi, P., Summer, A., and Abeni, F.: New insights into the quality characteristics of milk from Modenese breed compared with Italian Friesian, Ital. J. Anim. Sci., 15, 559-567, 2016.

Soyeurt, H., Bruwier, D., Romnee, J. -M., Gengler, N., Bertozzi, C., Veselko, D., and Dardenne, P.: Potential estimation of major mineral contents in cow milk using mid-infrared spectrometry, J. Dairy Sci., 92, 2444-2454, 2009.

Sturaro, E., Cocca, G., Gallo, L., Mrad, M., and Ramanzin, M.: Livestock systems and farming styles in Eastern Italian Alps: an on-farm survey, Ital. J. Anim. Sci., 8, 541-554, 2010.

Summer, A., Franceschi, P., Malacarne, M., Formaggioni, P., Tosi, F., Tedeschi, G., and Mariani, P.: Influence of somatic cell count on mineral content and salt equilibria of milk, Ital. J. Anim. Sci., 8, 435-437, 2009.

Taylor, M. S., Knowlton, K. F., McGilliard, M. L., Seymour, W. M., and Herbein, J. H.: Blood mineral, hormone, and osteocalcin responses of multiparous Jersey cows to an oral dose of 25hydroxyvitamin D3 or vitamin D3 before parturition, J. Dairy Sci., 91, 2408-2416, 2008.

Toffanin, V., De Marchi, M., Lopez-Villalobos, N., and Cassandro, M.: Effectiveness of mid-infrared spectroscopy for prediction of the contents of calcium and phosphorus, and titratable acidity of milk and their relationship with milk quality and coagulation properties, Int. Dairy J., 41, 68-73, 2015.

Varotto, A., De Marchi, M., Penasa, M., and Cassandro, M.: A comparison of milk clotting characteristics and quality traits of Rendena and Holstein-Friesian cows, Ital. J. Anim. Sci., 14, 202206, 2015.

Visentin, G., Penasa, M., Gottardo, P., Niero, G., Isaia, M., Cassandro, M., and De Marchi, M.: Milk coagulation properties of cattle breeds reared in Alpine area, Poljoprivreda, 21, 237-240, 2015.

Visentin, G., Penasa, M., Gottardo, P., Cassandro, M., and De Marchi, M.: Predictive ability of mid-infrared spectroscopy for major mineral composition and coagulation traits of bovine milk by using the uninformative variable selection algorithm, J. Dairy Sci., 99, 8137-8145, 2016.

Visentin, G., Penasa, M., Niero, G., Cassandro, M., and De Marchi, M.: Phenotypic characterisation of major mineral composition predicted by mid-infrared spectroscopy in cow milk, Ital. J. Anim. Sci., 17, 549-556, 2018.

Wiggans, G. R. and Shook, G. E.: A lactation measure of somatic cell count, J. Dairy Sci., 70, 2666-2672, 1987.

Zamberlin, Š., Antunac, N., Havranek, J., and Samaržija, D.: Mineral elements in milk and dairy products, Mljekarstvo, 62, 111125, 2012. 